\title{
Willow Biomass as Energy Feedstock: The Effect of Habitat, Genotype and Harvest Rotation on Thermophysical Properties and Elemental Composition
}

\author{
Mariusz Jerzy Stolarski 1,*(D), Michał Krzyżaniak ${ }^{1}$ (D), Kazimierz Warmiński ${ }^{2}$, \\ Dariusz Załuski ${ }^{1}$ (D) and Ewelina Olba-Zięty ${ }^{1}$ (D)
}

1 Centre for Bioeconomy and Renewable Energies, Department of Plant Breeding and Seed Production, Faculty of Environmental Management and Agriculture, University of Warmia and Mazury, Plac Łódzki 3, 10-724 Olsztyn, Poland; michal.krzyzaniak@uwm.edu.pl (M.K.); dariusz.zaluski@uwm.edu.pl (D.Z.); e.olba-ziety@uwm.edu.pl (E.O.-Z.)

2 Centre for Bioeconomy and Renewable Energies, Department of Chemistry, Faculty of Environmental Management and Agriculture, University of Warmia and Mazury, Prawocheńskiego 17, 10-720 Olsztyn, Poland; kazimierz.warminski@uwm.edu.pl

* Correspondence: mariusz.stolarski@uwm.edu.pl; Tel.: +48-89-5234838

Received: 20 June 2020; Accepted: 5 August 2020; Published: 10 August 2020

\begin{abstract}
Willow biomass is used as a bioenergy source in various conversion technologies. It is noteworthy that apart from the beneficial environmental impact of a willow plantation, the biomass quality is also very important as it has an impact on the effectiveness of its use and emissions produced in various bioenergy technologies. Therefore, this study analysed the thermophysical properties and elemental composition of 15 genotypes of willow biomass from two plantations situated in the north of Poland, harvested in two consecutive three-year rotations. The differences in the moisture content, ash content and the lower heating value were mainly determined by the genotype, i.e., by genetic factors. In contrast, the content of carbon, nitrogen, sulphur and hydrogen was determined by the location (environmental factors), but also by the genotype, and by a combination of these factors. The following were the mean levels of the willow biomass characteristics, regardless of the location, genotype and harvest rotation: $48.9 \%$ moisture content, $1.26 \%$ d.m. ash content, $19.4 \%$ d.m. fixed carbon, $79.4 \% \mathrm{~d} . \mathrm{m}$. volatile matter, $19.53 \mathrm{MJ} \mathrm{kg}^{-1} \mathrm{~d}$.m. higher heating value, $8.20 \mathrm{MJ} \mathrm{kg}^{-1}$ lower heating value, $52.90 \%$ d.m. carbon, $6.23 \%$ d.m. hydrogen, $0.032 \%$ d.m. sulphur, $0.42 \%$ d.m. nitrogen. The present research has shown that the selection of the willow genotype is important for the quality of biomass as energy feedstock. However, plantation location, as well as successive harvest rotations, can have a significant impact on the biomass elemental composition.
\end{abstract}

Keywords: short rotation coppice; Salix; genotype $\times$ site interaction; ash content; lower heating value; nitrogen content; sulphur content

\section{Introduction}

Due to increasing levels of $\mathrm{CO}_{2}$ in the atmosphere resulting from anthropogenic activities, and many European Union (EU) countries striving to increase their energy independence, there is growing interest in the use of renewable energy sources (RES), which are successfully replacing fossil fuels [1-5]. Although the use of each RES type is important, the portion of each RES in energy production is different in each country and depends on the geographic latitude, size and demographic structure of a country. In general, bioenergy, especially solid biomass, is of the greatest importance 
in EU countries [6]. Bioenergy also plays a particularly important role in Poland, as it accounted for nearly $85 \%$ of energy production from RES in 2018, with solid biofuels accounting for over $69 \%$ [7]. Due to a large forest area in Poland (over 9 million ha, which accounts for approx. 30\% of the country area) and the amount of wood acquired annually (over 40 million $\mathrm{m}^{3}$ ) [8], wood processing industry waste and post-felling biomass, i.e., branches and twigs left over after tree felling, is the dominating source of woody biomass. Plantations of woody crops grown as short rotation coppice (SRC) are another source of woody biomass and include mainly willow and poplar [9-13]. The area of poplar and willow cultivation in the SRC system in Poland is estimated at approx. 16.8 thousand ha [14]. Therefore, assuming a mean yield of $8.5 \mathrm{Mg} \mathrm{ha}^{-1}$ year ${ }^{-1} \mathrm{~d}$.m., this kind of plantation can potentially give ca. $142,800 \mathrm{Mg}$ year $^{-1}$ d.m.

The perennial nature of SRC crops and low demand for nutrients with limited agricultural procedures were shown to have a positive impact on the GHG balance and carbon accumulation in soil [15-18]. Moreover, a life cycle assessment of willow and poplar biomass production has shown that yield is a very important factor affecting the GHG balance, and that fertilisation can have negative effects [19]. It is noteworthy that apart from the beneficial environmental impact of an SRC plantation and the yield, the biomass quality is also very important as it has an impact on the effectiveness of its use and emissions produced in various bioenergy technologies. Woody biomass, including willow and poplar, is successfully used as an energy feedstock in the combustion of chips, pellet and briquette [20-23]. Increasing attention has been attracted recently by the cascade use of lignocellulosic biomass. This concept involves the acquisition of valuable bioactive substances and post-extraction biomass is used for energy production. Moreover, woody biomass is being studied for the production of second-generation transport biofuels [24,25]. However, if these technologies of lignocellulosic biomass conversion continue to develop commercially, they will require a continuous supply of raw material of consistent quality.

Lignocellulosic biomass quality depends on several factors, especially the type of plant and biomass. In general, woody biomass obtained from SRC (willow, poplar, black locust) is characterised by a higher content of lignin and greater higher heating value (HHV) as well as a lower content of hemicellulose, ash and chlorine compared to grasses and herbaceous crops $[26,27]$. Therefore, woody biomass is usually regarded as good material for thermal conversion. On the other hand, ash and other mineral biomass components may pose a problem for thermal and thermochemical conversion technologies as they cause corrosion and the formation of slag and sediments. Furthermore, the ash present in biomass can decrease the effectiveness of its pre-treatment in biochemical conversion processes. Therefore, the biomass quality characteristics and understanding the source of variability are of great importance [28]. This is particularly important in the case of willow because of the large number and diversity of species, cultivars and clones. Significant differences in bark and ash content were found in initial breeding experiments on many willow genotypes of many species in the USA [29,30]. Later studies also revealed great differences between 18 willow genotypes with respect to polysaccharides and ash and considerable genotype interactions with the environment for some characteristics [11]. Therefore, both genetic factors and environmental and agrotechnical conditions have a significant effect on the composition and quality of biomass [28,31-34]. Research in Poland on willow production, biomass quality and its use for energy purposes also accelerated at the beginning of this century [10,35]. Willow has become one of the perennial crops grown in Poland for energy or industrial purposes in two cultivation systems, mainly as SRC and Eko-Salix, which differ primarily in the method of setting up and managing the plantation and the duration of a harvest rotation [10]. However, studies on the topic have usually concerned only a few clones, locations and harvest rotations, whereas the present research covers a dozen promising, preselected willow cultivars and clones, which are suitable for cultivation as SRC under the climatic conditions of Poland as well as in central Europe. Therefore, the main aim of the current study was to evaluate the thermophysical properties and elemental composition of the biomass of 15 willow genotypes (including 7 cultivars and 8 clones) as energy feedstock, harvested at two different sites in two consecutive three-year 
harvest rotations. These data were subsequently used for the quantitative determination of the relative contribution of genetic and site-related factors, and their interactions in explaining the variability of biomass characteristics. Moreover, the study aimed to determine the effect of genetic and site-related diversity on willow biomass quality.

\section{Materials and Methods}

\subsection{The Field Experiments}

The study was based on two field experiments at the University of Warmia and Mazury in Olsztyn (UWM), conducted in the north of Poland in 2013-2018. The first experiment was conducted in the village of Bałdy in the Warmińsko-Mazurskie Voivodship (53 $35^{\prime} 48^{\prime \prime} \mathrm{N}, 20^{\circ} 36^{\prime} 12^{\prime \prime}$ E) on mud-muck soil developed on calcareous gyttia in loamy subsoil. This experiment was set up in 2008 and the plants were harvested in 2008-2012 in one-year harvest rotations. Subsequently, beginning with 2013, the plants were harvested twice in two consecutive three-year rotations: 1st rotation, plant growing years 2013-2015; 2nd rotation, plant growing years 2016-2018; The second plant experiment was located in the village of Obory, the Pomeranian Voivodship ( $\left.53^{\circ} 43^{\prime} 34^{\prime \prime} \mathrm{N}, 18^{\circ} 53^{\prime} 55^{\prime \prime} \mathrm{E}\right)$, on complete humic heavy alluvial soil, formed from silty clay. This experiment was set up in 2009 and plants were harvested in 2009-2012 in one-year harvest rotations. Subsequently, beginning with 2013, the plants were harvested twice in two consecutive three-year rotations, like in Bałdy. Both experiments were conducted on good, fertile soils. However, they were approx. $150 \mathrm{~km}$ apart, so the climatic conditions were different. The annual average temperature during the experiment at Obory $\left(9.0^{\circ} \mathrm{C}\right)$ was higher by approx. $0.7^{\circ} \mathrm{C}$ compared to the temperature at Bałdy. The total annual precipitation at Bałdy (six-year average $-598 \mathrm{~mm}$ ) was higher by approx. $20 \%$ than at Obory. The rainfall at Bałdy during the study period ranged from 484 to $803 \mathrm{~mm}$, with that at Obory ranging from 454 to $640 \mathrm{~mm}$, in 2014 and 2017, respectively. Moreover, the groundwater level at both sites was suitable for willow cultivation since it ranged from ca. $80 \mathrm{~cm}$ to ca. $190 \mathrm{~cm}$ depending on the season and rainfall.

Fifteen willow genotypes of nine different species and interspecies hybrids were grown at both locations. These included seven cultivars of Salix viminalis (Start, Sprint, Turbo, Tur, Kortur, Oltur, Zubr) bred at the UWM, which are registered in the Polish entity which maintains the cultivar register, the Research Centre for Cultivar Testing in Stupia Wielka, and eight clones of other species from the UWM collection: S. acutifolia (clone number - UWM 093), S. alba (UWM 095), S. dasyclados (UWM 155), S. fragilis (UWM 195), S. pentandra (UWM 035), S. triandra (UWM 198), S. viminalis $\times$ S. amygdalina (UWM 054), S. viminalis $\times$ S. purpurea (UWM 033). Those 15 different willow clones were chosen which seemed interesting and prospective at the time of setting up the experiments. However, in order to verify it, similar studies at various sites were necessary, as presented in this paper.

The same mineral fertilisation was applied at both sites before the next harvest rotation started (April 2013 and 2016). Nitrogen (N) was applied as ammonium nitrate at a rate of $90 \mathrm{~kg} \mathrm{ha}^{-1}$. Phosphorus (P) was applied as triple superphosphate at $13 \mathrm{~kg} \mathrm{ha}^{-1}$. Potassium was applied as potassium salt at $50 \mathrm{~kg} \mathrm{ha}^{-1}$.

\subsection{Examination of Willow Biomass Quality}

Three-year-old willows were cut down manually with chainsaws in both experiments after the growing seasons ended. The harvest time was set when the soil was frozen, so willow was harvested in winter of the next year at both sites, i.e., in February 2016 and 2019. Representative biomass samples with a total mass of ca. $3 \mathrm{~kg}$ were collected during the harvest from whole plants of each cultivar and clone. The samples were packed into plastic bags and transported to the laboratory for analyses. First, the moisture content was determined at the temperature of $105^{\circ} \mathrm{C}$ by the oven-dry method (EN ISO 18134-1:2015). The plant harvest, transport of tightly packed biomass samples and the laboratory work were planned so that the moisture content was determined on the next day after harvest, which eliminated potential additional moisture loss. After the biomass samples were dried 
and their moisture content calculated, the samples were ground in a laboratory mill with a $1 \mathrm{~mm}$ mesh sieve, which produced a homogeneous fraction for further analyses. The ground samples from each cultivar and clones from the two experiments were subsequently stored in closed laboratory containers and used for further analyses. Before the HHV was determined, the samples were placed in an oven at $105^{\circ} \mathrm{C}$, and analytical samples were collected from them and placed in a bomb calorimeter IKA C2000. HHV was determined by the dynamic method. Furthermore, a Eltra Tga-Thermostep thermogravimetric oven was used to determine the ash content at $550{ }^{\circ} \mathrm{C}$ and volatile matter and fixed carbon content at $650^{\circ} \mathrm{C}$ (PN-EN ISO 18122:2016-01 and PN-EN ISO 18123:2016-01). Carbon (C), hydrogen $(\mathrm{H})$ and sulphur $(\mathrm{S})$ contents were then determined in an Eltra CHS 500 automatic analyser (PN-EN ISO 16948:2015-07 and PN-EN ISO 16994:2016-10). A total nitrogen assay in biomass was performed using Kjeldahl's method on a K-435 mineraliser and a B-324 Buchi distiller. The lower heating value (LHV) of each willow cultivar and clone biomass from the two sites in consecutive harvest rotations was calculated from the HHV, moisture content and hydrogen content, determined earlier in the laboratory (PN-EN ISO 18125:2017-07). All analyses were performed in three replicates, which means that altogether 12 biomass samples were analysed for each genotype $(2$ sites $\times 2$ harvest rotations $\times 3$ replicates) and the total number of analyses performed in the study was 180 ( 2 sites $\times 2$ harvest rotations $\times 15$ genotypes $\times 3$ replicates).

\subsection{Statistical Analysis}

All ten characteristics of biomass quality: moisture content, ash content, fixed carbon content, volatile matter, HHV and LHV and the contents of carbon, hydrogen, sulphur and nitrogen were subjected to separate (unidimensional) statistical analyses. A repeated-measures ANOVA test was applied, with the effect of locations (Loc) and the effect of 15 willow genotypes (Gen) being the grouping factors and harvest rotations (Rot) being the repeated measure factor. This model took into account all possible interactions between the experimental factors mentioned above. The replications (experimental blocks) were nested in the location effect (Rep(Loc)). The significance of the factors' effect and their interactions were verified at the significant level of $\alpha=0.05$. The percentage shares of all the effects under study in the total sum square (total SS) for a given analysis of variation were calculated. This yielded a measure of share in the variation under study, which was understood as the percent of explaining the variation by each individual analysis model effect. The significance of differences between the means was analysed with a Tukey test $(p<0.05)$, which was used to determine homogeneous sets.

A principal components analysis (PCA) was applied in the next stage, in which all ten biomass quality characteristics were analysed simultaneously. Since the characteristics under study were measured in different units and scales, the PCA was based on the results after the standardisation of characteristics, which was performed following the procedure for an unknown mean and the standard deviation for a population (1):

$$
z_{i}=\left(x_{i}-\text { mean }\right) / \text { std.dev }
$$

where $z_{i}$ is a variable following standardisation, $x_{i}$ is a variable before standardisation, mean is the mean of the sample and std.dev is the standard deviation of the sample.

The number of principal components for the PCA was determined by the Kaiser criterion, where the eigenvalues were greater than 1 . The PCA results were presented as a table of factor loadings and a biplot. All statistical analyses were conducted with STATISTICA 13.3 software (TIBCO Software Inc., Palo Alto, CA, USA, 2017).

\section{Results and Discussion}

\subsection{Thermophysical Properties of Willow Biomass}

The thermophysical characteristics (moisture content, ash content, fixed carbon, volatile matter, HHV and LHV) of willow biomass were differentiated by the site and genotype and the majority of 
them also by the harvest rotation and by the interactions of these factors (Table 1). The mean moisture content in willow biomass for all the genotypes sites and consecutive three-year harvest rotations was $48.9 \%$ (Figure 1). The contribution of the willow genotype to the biomass moisture content variation was the highest ( $81 \%$ of the total variation) (Table 1 ). In contrast, the interaction of location and genotype and consecutive harvest rotation did not have such a great impact on the variation of the willow biomass moisture content. The lowest mean moisture content was determined in the biomass of the Sprint cultivar (S. viminalis) and the highest was in the biomass of the UWM 155 clone (S. dasyclados) (45.2\% and 52.5\%, respectively) (Figure 1). Moreover, the willow biomass moisture content in this study was relatively low - it was below $50 \%$ in the majority of cases. In contrast, the biomass moisture content in willow harvested in 3- or 4-year rotations often exceeded 50\% [36-38]. The biomass moisture content in a longer, 7 -year rotation in S. alba exceeded $52 \%$, and it was below $50 \%$ in S. viminalis [10]. Therefore, this confirmed that the willow species differentiates the moisture content significantly. The differences are even more apparent between species of different SRC types because the moisture content in black locust is generally lower (ca. $40 \%$ ) and it is higher in poplar (ca. $60 \%$ ) when compared to the willow biomass [35]. Kauter et al. [39] also report that a high moisture content at harvest (up to 55-60\%) is one of the problematic features of woody biomass (poplar in this case). On the other hand, the weather conditions during the harvest as well as immediately before and after the harvest affect the biomass moisture content. Potential precipitation and high air humidity at harvest translate into an increase in the biomass moisture content. For this reason, the literature data for this biomass characteristic vary by up to several percentage points (pp) even within the same species and cultivation technology.

Table 1. Statistics $F$ from the repeated measure variation analysis and the percentage share of effects in the total variation for the thermophysical characteristics of willow biomass.

\begin{tabular}{|c|c|c|c|c|c|c|c|c|c|c|c|c|c|}
\hline \multirow{2}{*}{$\begin{array}{l}\text { Source of } \\
\text { Variation }\end{array}$} & \multirow{2}{*}{$d f$} & \multicolumn{2}{|c|}{ Moisture } & \multicolumn{2}{|c|}{ Ash } & \multicolumn{2}{|c|}{ Fixed Carbon } & \multicolumn{2}{|c|}{ Volatile Matter } & \multicolumn{2}{|c|}{ HHV } & \multicolumn{2}{|c|}{ LHV } \\
\hline & & $F$ & Share (\%) & $F$ & Share (\%) & $F$ & Share (\%) & $F$ & Share (\%) & $F$ & Share (\%) & $F$ & Share (\%) \\
\hline Location (Loc) & 1 & $31.3 * *$ & 0.4 & $11.8^{* *}$ & 0.6 & $104.9^{* *}$ & 10.3 & $127.4^{* *}$ & 9.9 & $763.0^{* * *}$ & 48.9 & 480.0 ** & 7.9 \\
\hline $\operatorname{Rep}(\operatorname{Loc})$ & 4 & 1.5 & 0.1 & 2.1 & 0.4 & 0.1 & 0.1 & 0.5 & 0.2 & 1.0 & 0.3 & 0.2 & 0.0 \\
\hline Loc $\times$ Gen & 14 & $42.8 * *$ & 6.7 & $3.6 * *$ & 2.5 & $8.1^{* *}$ & 11.1 & $8.2^{* *}$ & 9.0 & $5.9^{* *}$ & 5.3 & $29.0 * *$ & 6.7 \\
\hline Error 1 & 56 & - & 0.6 & - & 2.7 & - & 5.5 & - & 4.4 & - & 3.6 & - & 0.9 \\
\hline Rotation (Rot) & 1 & $29.8 * *$ & 0.3 & $136.0^{* *}$ & 11.3 & $221.4^{* *}$ & 20.2 & $397.7^{* *}$ & 26.0 & $37.5 * *$ & 2.2 & 2.8 & 0.0 \\
\hline Rot $\times$ Loc & 1 & $93.3 * *$ & 1.0 & $16.9^{* *}$ & 1.4 & 1.7 & 0.2 & 0.0 & 0.0 & $56.3^{* *}$ & 3.3 & $18.8^{* *}$ & 0.3 \\
\hline Rot $\times$ Loc $\times$ Gen & 14 & $36.6^{* *}$ & 5.4 & $3.3^{* *}$ & 3.9 & $14.9^{* *}$ & 19.1 & $15.4^{* *}$ & 14.1 & $9.7 * *$ & 8.1 & $20.8^{* *}$ & 5.1 \\
\hline Error 2 & 56 & - & 0.6 & - & 4.7 & - & 5.1 & - & 3.7 & - & 3.3 & - & 1.0 \\
\hline Total & & & 100.0 & & 100.0 & & 100.0 & & 100.0 & & 100.0 & & 100.0 \\
\hline
\end{tabular}

Share (\%); percentage share in the total sum of squares; ${ }^{* *} p<0.01$.

Like moisture content, the ash content in biomass was determined to the greatest extent by the willow genotype (nearly $66 \%$ ), followed by the harvest rotation (11\%) and-to a lesser extent-by the other factors and their interactions (Table 1). The mean ash content in willow biomass harvested in three-year rotations was $1.26 \% \mathrm{~d} . \mathrm{m}$. for all the genotypes and sites. (Figure 2). The ash content in biomass obtained at Obory (mean $1.25 \%$ d.m.) was lower by only 0.2 pp compared to that obtained at Bałdy. The lowest ash content of all the genotypes under study was determined in the biomass of the UWM 198 clone of S. triandra (mean $0.99 \%$ d.m.). The Tur and Żubr cultivars (S. viminalis) and the UWM 093 clone (S. acutifolia) contained less ash compared to the other genotypes. The highest ash content was determined in biomass of the UWM 155 clone of S. dasyclados (1.43\% d.m.). Therefore, the differences between the willow genotypes under study with respect to the ash content were large (up to $44 \%$ ). Thus, the ash content in the willow biomass was determined by the genotype, i.e., genetic factors that were decisive for it. However, one cannot definitely determine what other (e.g., physiological) factors affected this phenomenon. Nevertheless, the very fact of identifying statistically significant differences between genotypes is of high scientific and practical value for both biomass producers and end-users. Moreover, it was found in an extensive study covering several locations and several dozen willow genotypes that the ash content in biomass was determined mainly by the genotype and ranged from less than $1 \%$ d.m. to more than 3\% d.m. [28]. It was also shown that S. purpurea, 
which grows a large number of shoots of smaller diameter, contained less ash (ca. 1.6\% d.m.), compared to $S$. miyabeana, which grew fewer shoots with a larger diameter (ca. $2.2 \%$ d.m.) $[29,30,40,41]$. The ash content as determined in another study in a three-year harvest rotation also varied between species $(1.25-1.76 \%)$-it was the lowest in S. alba, and the highest in S. Smithiana [42]. The mean ash content in willow biomass harvested in a 3- and 4-year rotation was $1.4 \% \mathrm{~d} . \mathrm{m}$. and $1.2 \% \mathrm{~d} . \mathrm{m}$., respectively [36]. Even higher ash content in willow biomass (1.9-3\%) was found in another study [38,43]. Furthermore, the mean ash content in six willow genotypes harvested in a 7-year harvest rotation at three different sites was $1.3 \%$ d.m. [10]. Some authors have pointed out that the ash content decreases as the harvest cycle becomes longer [44,45]. Obviously, the ash content levels mentioned above should be regarded as generally low compared to the ash content in other biomass types, such as semi-woody biomass, straw and palm kernel shell $[35,46,47]$.

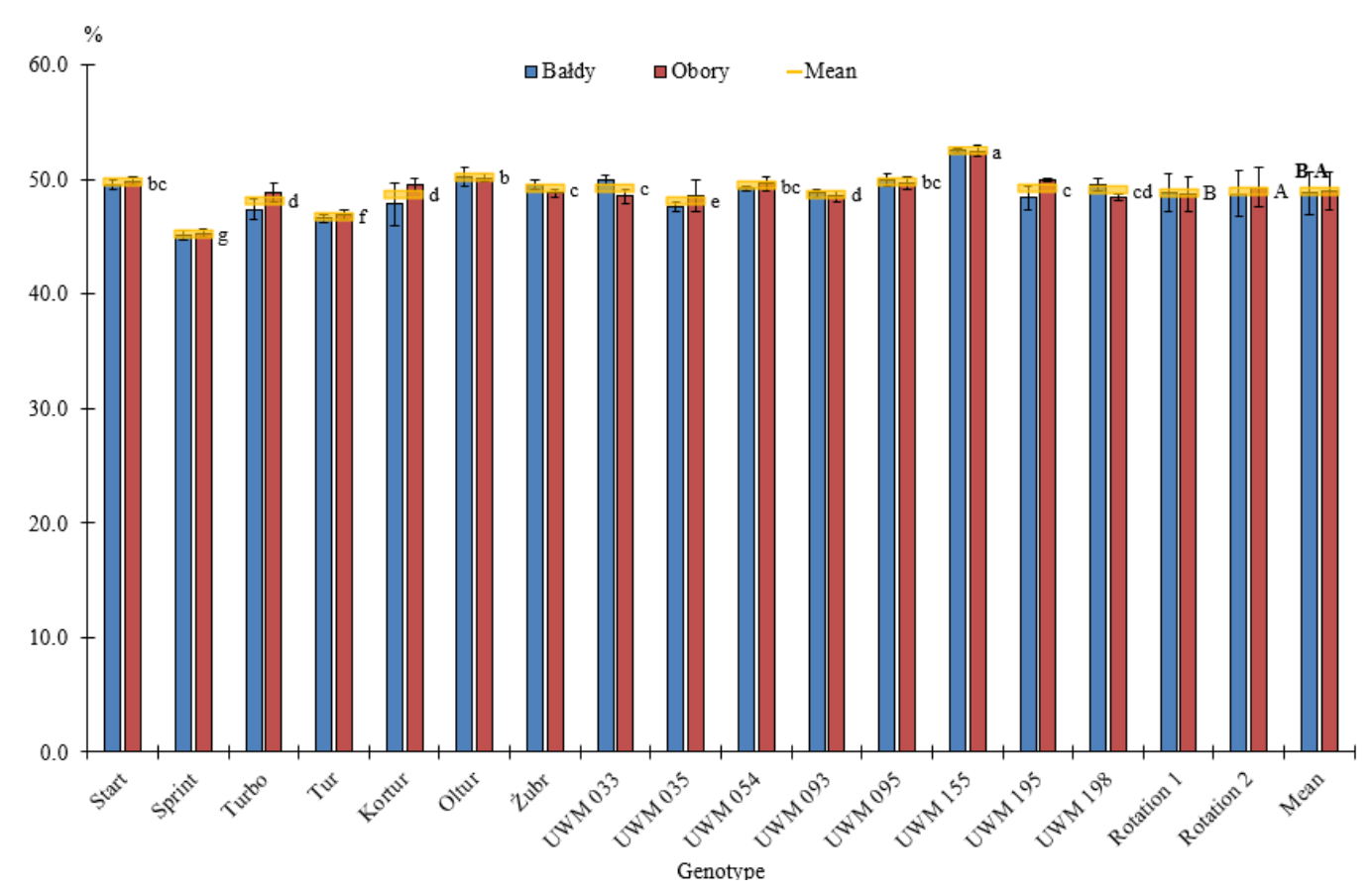

Figure 1. Moisture content in the biomass of 15 willow genotypes obtained at two locations in two consecutive three-year harvest rotations; (error bars determine standard deviation; lower case letters $a, b, c$... denote homogeneous sets in Tukey's test for mean values calculated for genotypes regardless of the location; capital letters A,B denote homogeneous sets for mean values calculated for the harvest rotation; bold capital letters A,B denote homogeneous sets for mean values calculated for the habitats; ns denotes insignificant differences).

Fixed carbon and volatile matter content were determined to the greatest extent by the harvest rotation ( $20 \%$ and $26 \%$, respectively) (Table 1$)$. However, unlike for moisture content and ash content, an important role was played in the case of these two characteristics by other factors, such as the genotype (16\% and $22 \%$, respectively) and location (approx. 10\%) and their interaction $(9 \%$ and $19 \%$, respectively). Therefore, it can be claimed that fixed carbon and volatile matter content were determined by all the main factors and their interactions and it is difficult to identify the factor with the greatest impact. The mean fixed carbon was $19.4 \% \mathrm{~d} . \mathrm{m}$. and it was slightly higher in the second harvest rotation and at Bałdy (Figure 3). Meanwhile, the mean value of this characteristic in the genotypes under study ranged from $18.8 \%$ d.m. to $19.7 \%$ d.m. The mean volatile matter content was $79.4 \%$ d.m. and it was slightly higher in the first harvest rotation and at Obory, and the maximum difference between the genotypes under study was $1.1 \mathrm{pp}$ (Figure 4). The volatile matter content in willow biomass as determined in other studies ranged from $79 \%$ d.m. to over $83 \%$ d.m. [10,37]. It also lay within this range when determined for other willow species harvested in a three-year rotation [42]. 


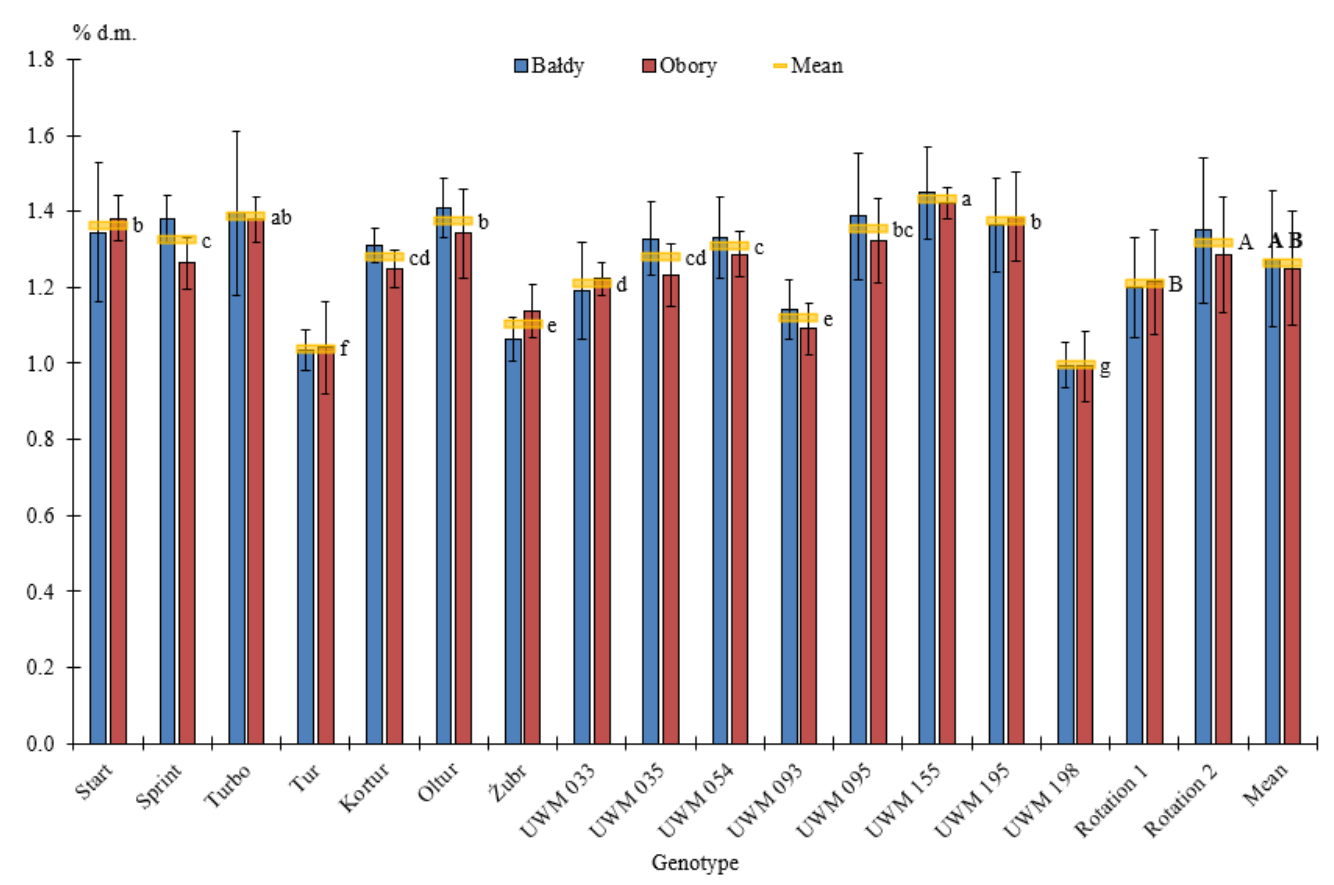

Figure 2. Ash content in the biomass of 15 willow genotypes obtained at two locations in two consecutive three-year harvest rotations; (legend: see Figure 1).

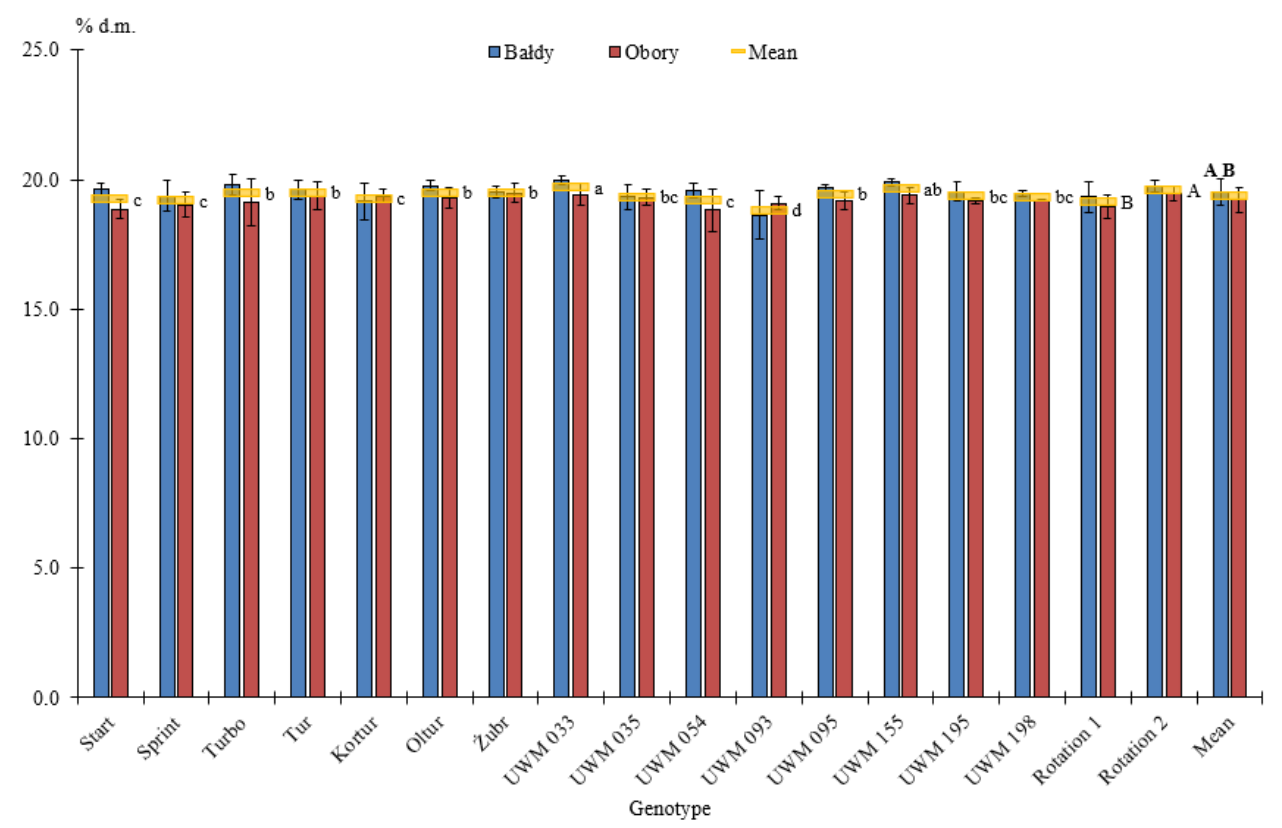

Figure 3. Fixed carbon content in the biomass of 15 willow genotypes obtained at two locations in two consecutive three-year harvest rotations; (legend: see Figure 1).

The analyses showed that HHV was determined to the greatest extent by location (49\%), which was rather surprising. However, it appeared that the genotype (20\%) also had a significant impact on this characteristic (Table 1). Different relationships were also observed in the case of the LHV, as this characteristic was found to be determined by the genotype to the greatest extent $(75 \%)$, while the location determined it only by $8 \%$. The mean HHV throughout the experiment was $19.53 \mathrm{MJ} \mathrm{kg}^{-1} \mathrm{~d} . \mathrm{m}$., regardless of the location, genotype or harvest rotation. (Figure 5). The mean value of this characteristic for Bałdy was $19.68 \mathrm{MJ} \mathrm{kg}^{-1}$ d.m. and it was higher than at Obory by $0.3 \mathrm{MJ} \mathrm{kg}^{-1} \mathrm{~d} . \mathrm{m}$. Among the genotypes under study, the highest HHV was determined for the biomass of the UWM 093 
clone of S. acutifolia (mean $19.79 \mathrm{MJ} \mathrm{kg}^{-1} \mathrm{~d}$.m.). It was lower by approx. $2 \%$ in the Żubr cultivar of S. viminalis and it was the lowest $\mathrm{HHV}$ among all the genotypes under study. Furthermore, the mean LHV, calculated from the HHV, moisture content and hydrogen content, was $8.20 \mathrm{MJ} \mathrm{kg}^{-1}$ (Figure 6). However, it is noteworthy that the difference between the Sprint cultivar with the highest value of this characteristic (8.93 $\mathrm{MJ} \mathrm{kg}^{-1}$ S. viminalis) and the genotype with the lowest LHV (UWM 155 S. dasyclados) was nearly $17 \%$. The mean LHV for biomass obtained at Bałdy was higher by approx. $3 \%$ compared to the mean value at Obory. The LHV determined in other studies for different willow genotypes harvested in 3-year rotations ranged from $7.7 \mathrm{MJ} \mathrm{kg}^{-1}$ to $9.3 \mathrm{MJ} \mathrm{kg}^{-1}$ [36,37]. Similar LHV was calculated for willow harvested in a 4-year and a longer, 7 -year harvest rotation [10,36,38].

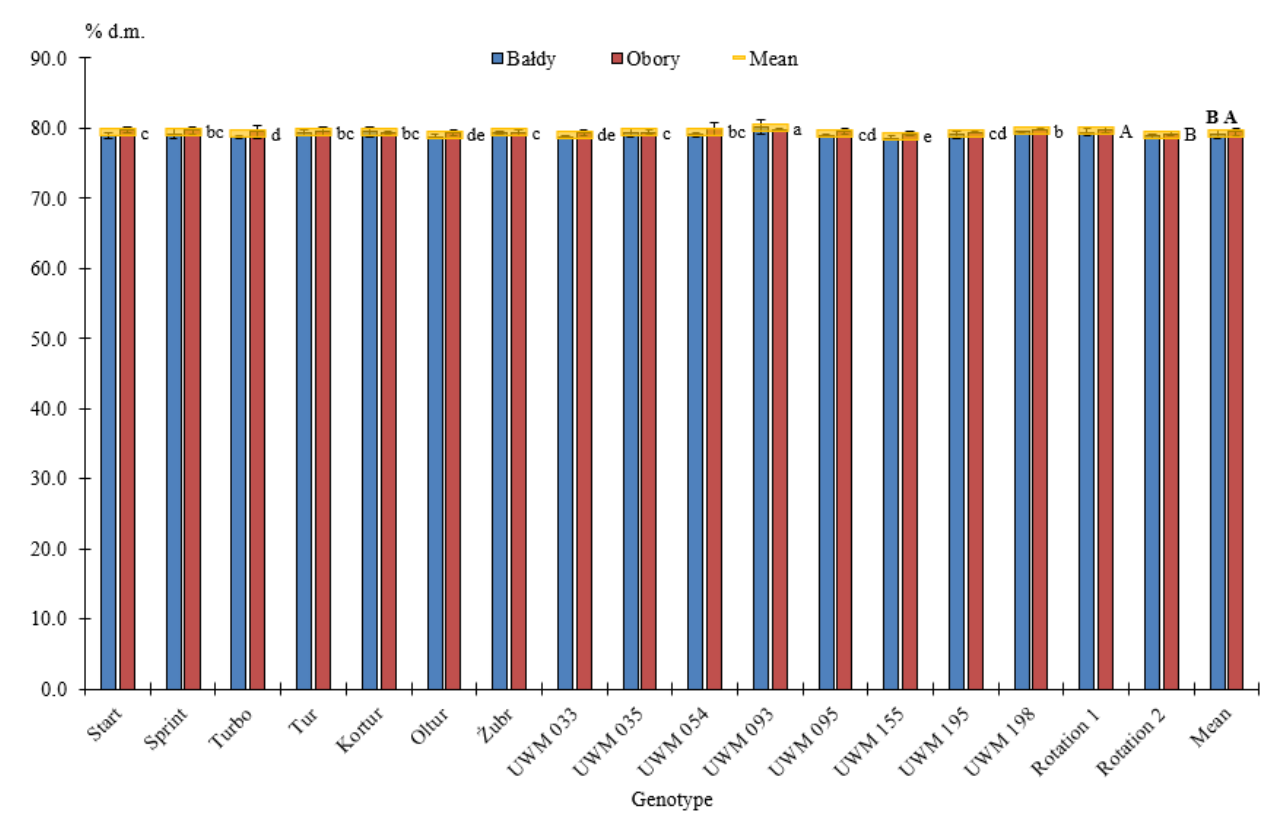

Figure 4. Volatile matter content in the biomass of 15 willow genotypes obtained at two locations in two consecutive three-year harvest rotations; (legend see Figure 1).

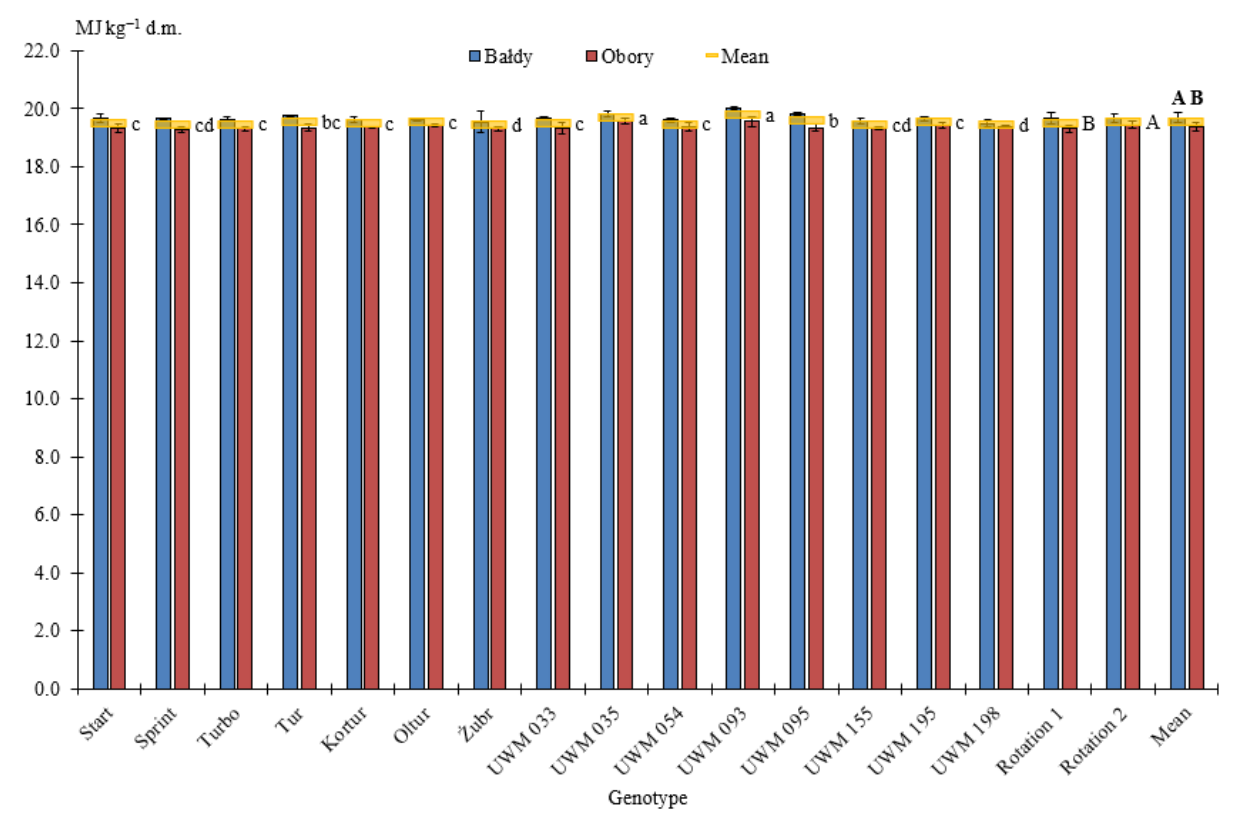

Figure 5. Higher heating value (HHV) of the biomass of 15 willow genotypes obtained at two locations in two consecutive three-year harvest rotations; (legend: see Figure 1). 


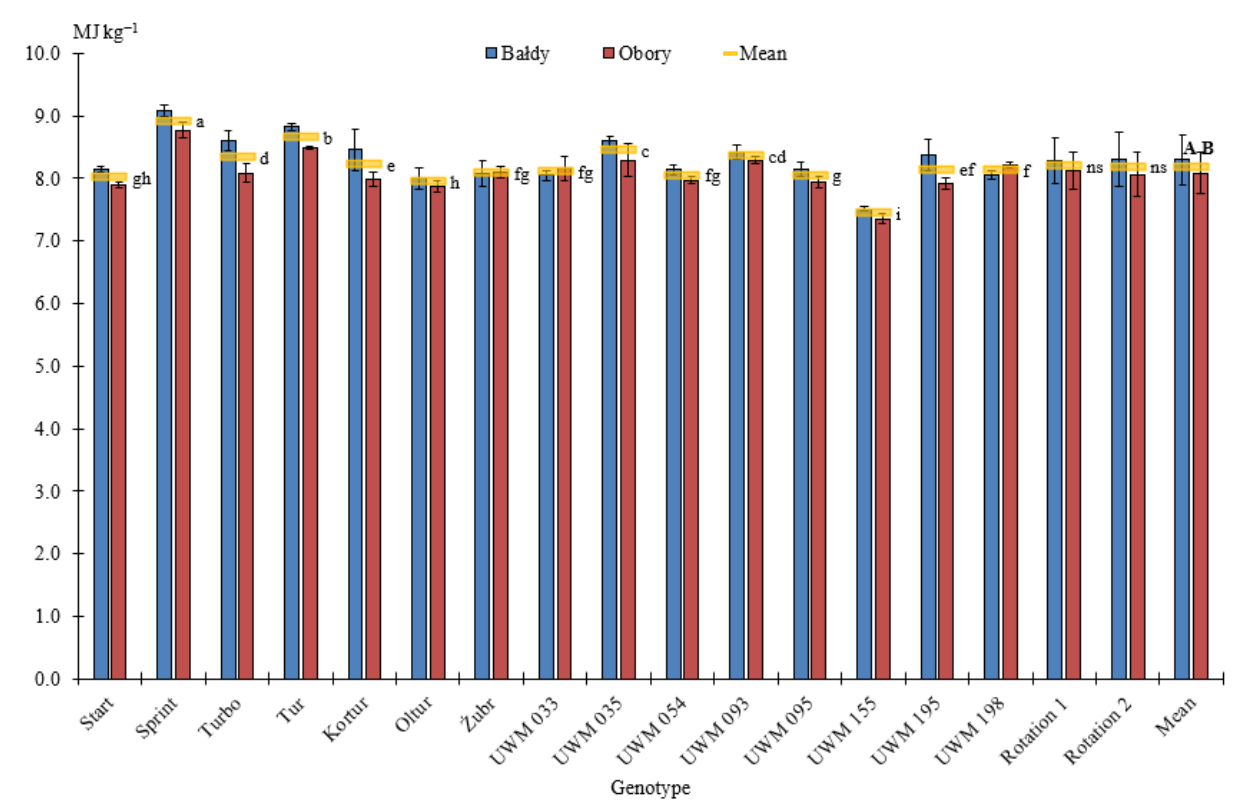

Figure 6. Lower heating value (LHV) of the biomass of 15 willow genotypes obtained at two locations in two consecutive three-year harvest rotations; (legend: see Figure 1).

\subsection{Elemental Composition of Willow Biomass}

The carbon $(\mathrm{C})$, hydrogen $(\mathrm{H})$ and nitrogen $(\mathrm{N})$ contents in biomass were significantly differentiated by all three main factors (location, genotype, harvest rotation) and the interactions between them. The absence of any significant impact in the case of sulphur (S) was observed only for the harvest rotation (Table 2). In the case of $C$, the location had the greatest contribution to the variation of this characteristic (35\%), followed by the genotype and interactions of these factors. The mean $\mathrm{C}$ content in biomass, regardless of the location, genotype and harvest rotation was $52.90 \% \mathrm{~d}$.m. (Figure 7). It exceeded $53 \%$ d.m. in six genotypes, and it ranged from $52.3 \%$ to $52.9 \%$ d.m. in the other nine. Moreover, the mean $\mathrm{C}$ content in biomass obtained at Bałdy $(53.3 \%$ d.m.) was higher by $0.9 \mathrm{pp}$ compared to the biomass obtained at Obory. The mean content of $C$ in willow biomass in a 3- and 4-year harvest rotation, as determined in other studies, was lower than in the current experiment and amounted to $51 \%$ and $49 \%$ d.m., respectively [36-38]. The carbon content determined in S. alba $(50.2 \%)$ biomass in a 3-year rotation in another study was higher by $0.8 \mathrm{pp}$ than in S. viminalis [42]. A similar mean $C$ content (51\% d.m.) was also found in willow biomass harvested in a 7-year rotation [10].

Table 2. Statistics $F$ from the repeated measure variation analysis and the percentage share of effects in the total variation for the elemental composition of willow biomass.

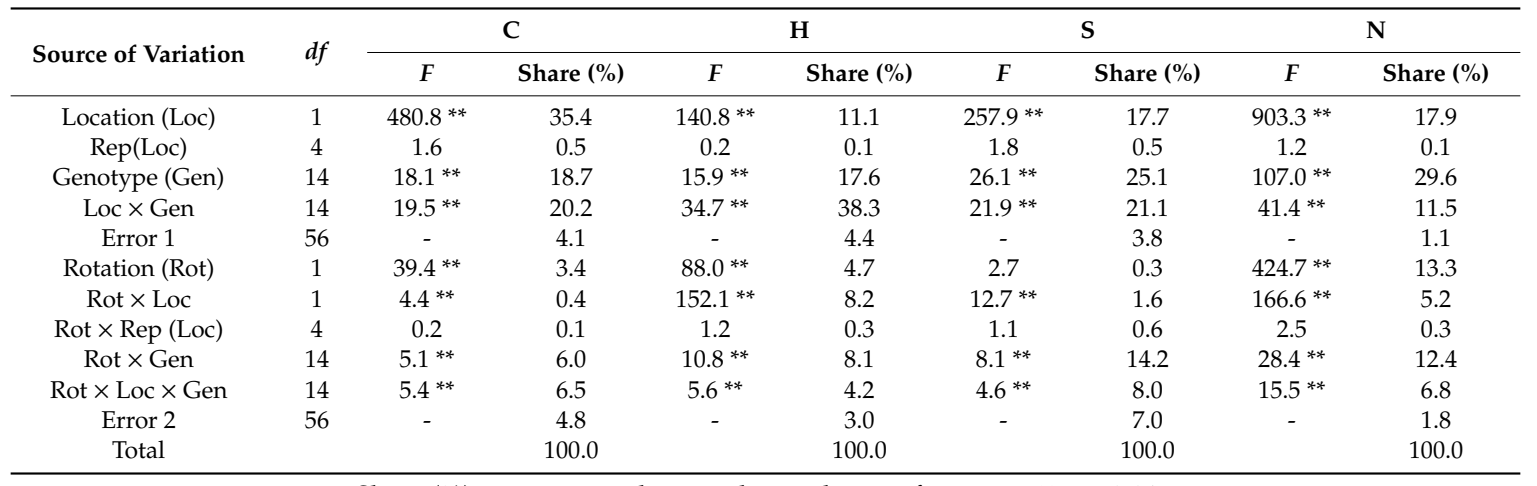

Share (\%); percentage share in the total sum of squares; ${ }^{* *} p<0.01$. 


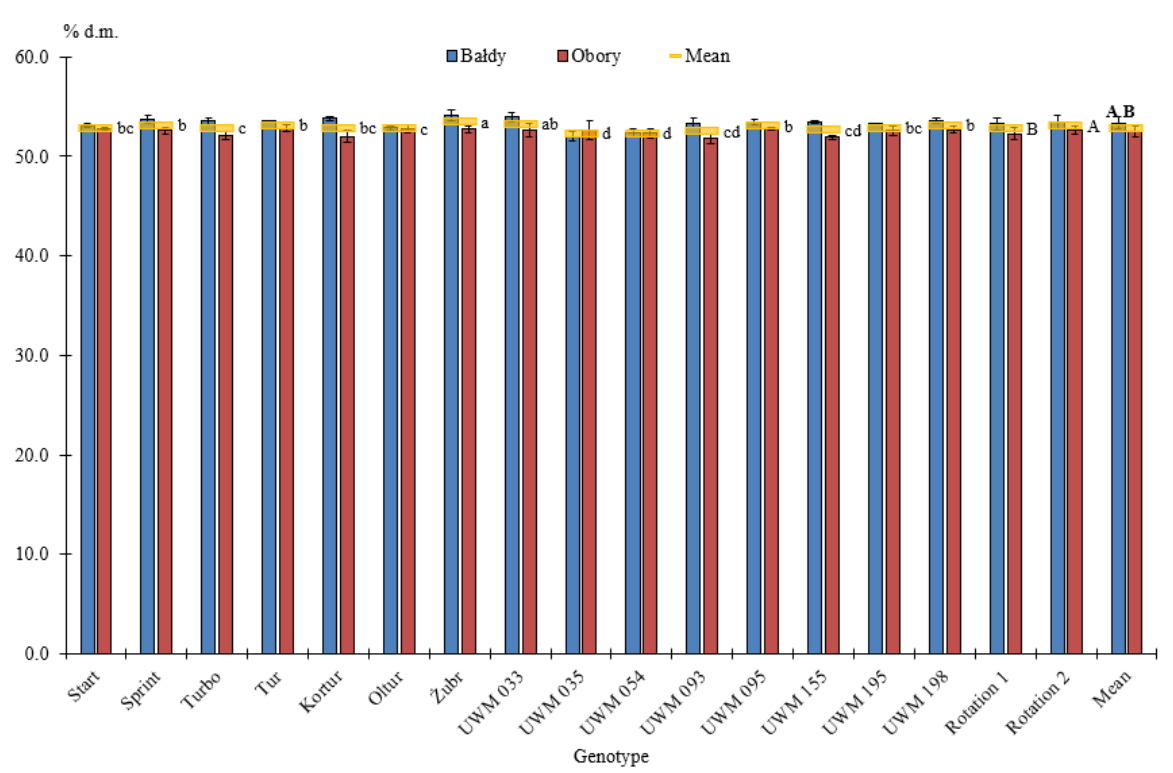

Figure 7. Carbon content in the biomass of 15 willow genotypes obtained at two locations in two consecutive three-year harvest rotations; (legend: see Figure 1).

The $\mathrm{H}$ content in biomass was determined to the greatest extent by the interaction of location and genotype (38\%), followed by the genotype (18\%) and location (11\%) (Table 2). The mean H content in willow biomass was $6.23 \%$ d.m. (Figure 8 ). The biomass obtained at Obory contained more hydrogen by approx. $2 \%$ ( $6.31 \%$ d.m.) compared to the biomass obtained at Bałdy. Among the 15 genotypes under study, the mean value of this characteristic ranged from $6.03 \%$ d.m. to $6.43 \%$ d.m., for the genotypes of UWM 155 (S. dasyclados) and UWM 093 (S. acutifolia). It was also shown in other studies that the hydrogen content in willow biomass was close to, or exceeded, $6 \%$ d.m. [10,36-38].

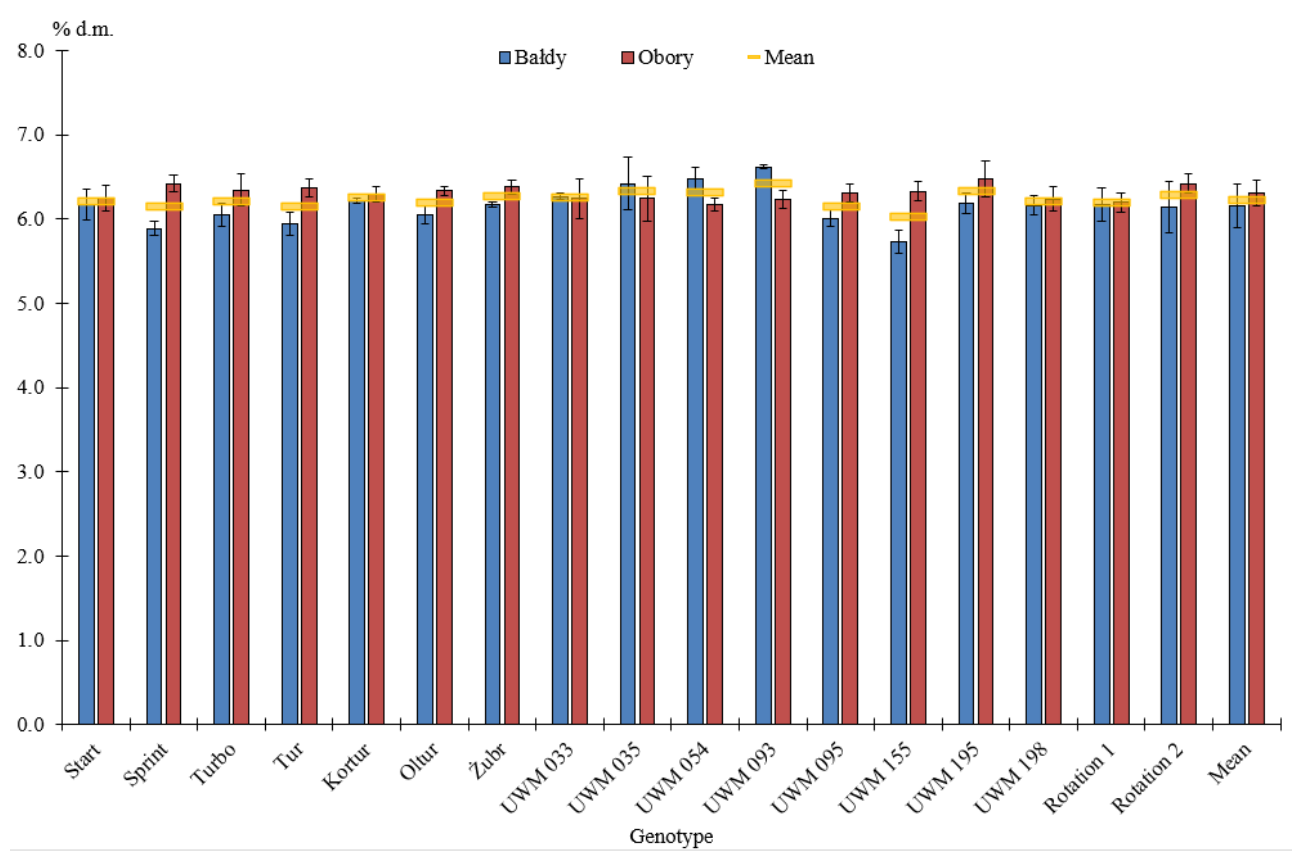

Figure 8. Hydrogen content in the biomass of 15 willow genotypes obtained at two locations in two consecutive three-year harvest rotations; (legend: see Figure 1).

The $\mathrm{S}$ content was determined to the greatest extent by the genotype $(25 \%)$, followed by the interaction of location and genotype (21\%) and by location (18\%) (Table 2). The mean S content in 
the biomass was $0.032 \%$ d.m. (Figure 9). The sulphur content in the biomass at Bałdy $(0.035 \%$ d.m.) was higher by approx. 19\% than in the biomass at Obory. The values of this characteristic for the 15 genotypes under study ranged from 0.026 to $0.037 \%$ d.m., for the UWM 195 genotype (S. fragilis) and the Tur cultivar (S. viminalis) and the UWM 035 genotype (S. pentandra), respectively. This indicates that the differences in the sulphur content between the willow genotypes were rather large (up to $28 \%$ ). The sulphur content in biomass determined in another study of the willow hybrid S. trianda $\times$ S. viminalis was ca. $0.03 \%$ d.m. [38]. More diverse values of this characteristic $(0.014-0.048 \%$ d.m. $)$ were found in studies of different willow genotypes harvested in a three-year rotation [37]. On the other hand, the mean S content in biomass obtained in a 7-year rotation was $0.039 \% \mathrm{~d}$.m., ranging from $0.029 \%$ d.m to $0.052 \%$ d.m., for UWM 200 and the Turbo cultivar, respectively [10]. A still higher sulphur content (mean $0.070 \%$ d.m.) was determined in three-year biomass of the Inger cultivar willow grown at two sites in Denmark [33]. Moreover, this characteristic as measured in eight cultivars harvested at two different sites ranged from 0.055 to $0.082 \%$ d.m., for the Tordis and Terra Nowa cultivars, respectively.

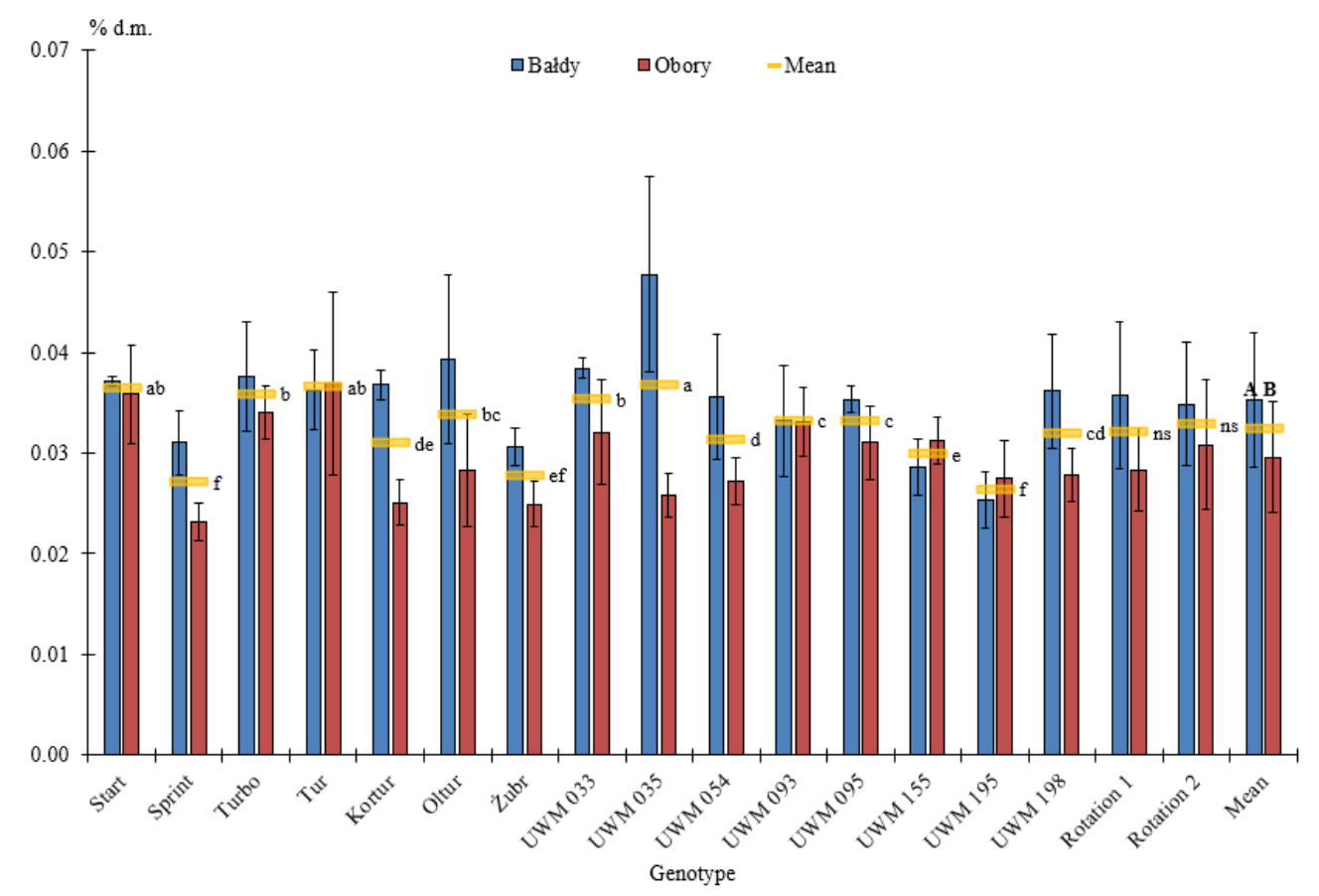

Figure 9. Sulphur content in the biomass of 15 willow genotypes obtained at two locations in two consecutive three-year harvest rotations; (legend: see Figure 1).

The $\mathrm{N}$ content in willow biomass was determined to the greatest extent by the genotype (30\%), followed by location (18\%) and harvest rotation (13\%) (Table 2). The mean $\mathrm{N}$ content in biomass was $0.42 \%$ d.m. (Figure 10). The value of this characteristic was higher by approx. $16 \%$ in biomass obtained at Bałdy $(0.45 \%$ d.m.) than at Obory. The values of this characteristic for the 15 genotypes under study ranged from $0.36 \%$ d.m to $0.51 \%$ d.m., for the Tur cultivar (S. viminalis) and the UWM 155 genotype (S. dasyclados), respectively. Therefore, the differences in the nitrogen content between the willow genotypes (29\%) were high. Moreover, the willow biomass obtained in the second three-year harvest rotation $(0.45 \%$ d.m.) contained more nitrogen by approx. $12 \%$ compared to the biomass harvested in the first rotation. The $\mathrm{N}$ content in willow biomass determined in other studies was also similar $(0.46 \%$ d.m.) [38]. Furthermore, the $\mathrm{N}$ content in willow biomass harvested in a 3-year rotation in another study reached $0.61 \% \mathrm{~d} . \mathrm{m}$. [37]. Large significant differences in the nitrogen content (range $0.39-0.75 \%$ d.m.) in biomass of three-year old willow were also observed in Denmark between eight cultivars and two sites [33]. The mean $\mathrm{N}$ content in biomass harvested in a 7-year rotation was 
$0.32 \%$ d.m. [10]. Other studies also demonstrated considerable differences in the content of the assayed elements, both between sites and between cultivars and willow harvest rotations [48-52].

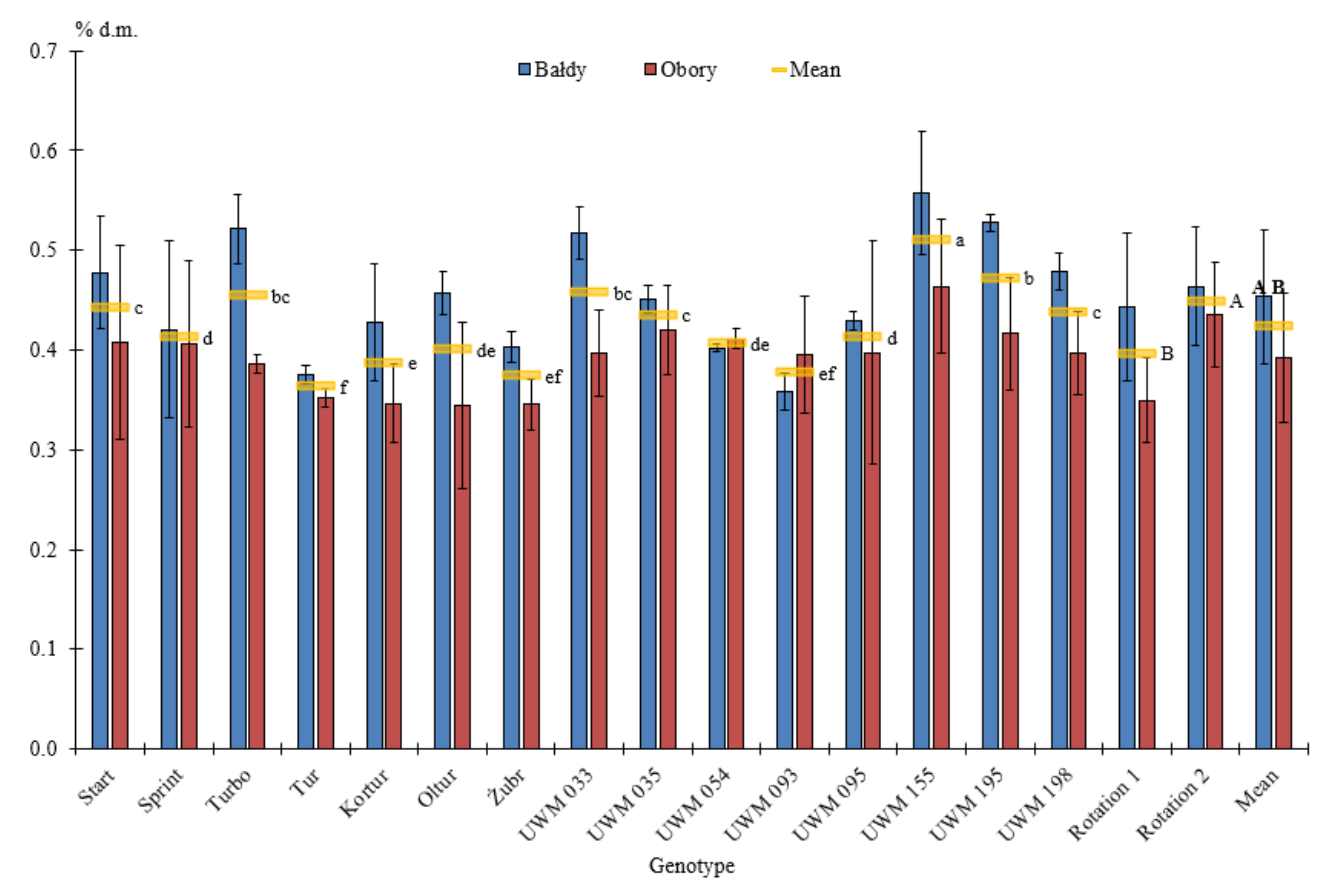

Figure 10. Nitrogen content in the biomass of 15 willow genotypes obtained at two locations in two consecutive three-year harvest rotations; (legend: see Figure 1).

3.3. Principal Component Analysis (PCA) and an Assessment of the Impact of the Factors under Analysis on Willow Biomass Properties

The principal component analysis (PCA) used standardised values of all the biomass quality characteristics. The biplot showed that the willow genotypes grown at Bałdy are distinctly separated from those grown at Obory (Figure 11). This was caused by the first principal component PC1 which explained nearly $31 \%$ of the variation. The components included fixed carbon and the $\mathrm{C}$ and $\mathrm{N}$ contents, which had a positive sign of the factorial load (Table 3) and "pulled" nearly all the willow genotypes at Bałdy to the right of the graph. The opposite, left side of component PC1, with small exceptions, mainly included the genotypes growing at Obory, whose biomass contained high levels of hydrogen and volatile matter. It was found that these five biomass characteristics had a large strength of discrimination, i.e., separation of the two locations (sites). It is noteworthy that these characteristics had a great percentage share of the effects of the location $\times$ genotype interaction and in the principal effect of the location. The second principal component of the PCA is a purely genetic effect arising from the moisture and ash content in biomass and the LHV, which is negatively correlated with them. The effect of the PC2 component was based on the significant distinguishing of the genotypes at the locations under study. This principal component explained $24.3 \%$ of the total variation. The third principal component PC3 is an effect of the variation of HHV and sulphur content in biomass, which explained nearly $17 \%$ of the total variation. All three significant components PC1, PC2 and PC 3 together explained $72 \%$ of the variation under analysis.

It is noteworthy that from among all the willow biomass characteristics, the sulphur content variation coefficient was the highest (20.8\%) (Table 4). Among the principal factors under analysis, the sulphur content was differentiated to the greatest extent by location $(16.9 \%)$, followed by rotation (13.3\%) and genotype $10.8 \%$. The variation coefficient for the nitrogen content in biomass was also high $(17.2 \%)$. Moreover, the value order of the principal components under analysis was identical to the sulphur content. Ash content was the third biomass characteristic with a coefficient of variation 
above $10 \%$. The coefficients of variation for the other characteristics under analysis were lower than $5 \%$ and the lowest values of this characteristic were calculated for volatile matter content.

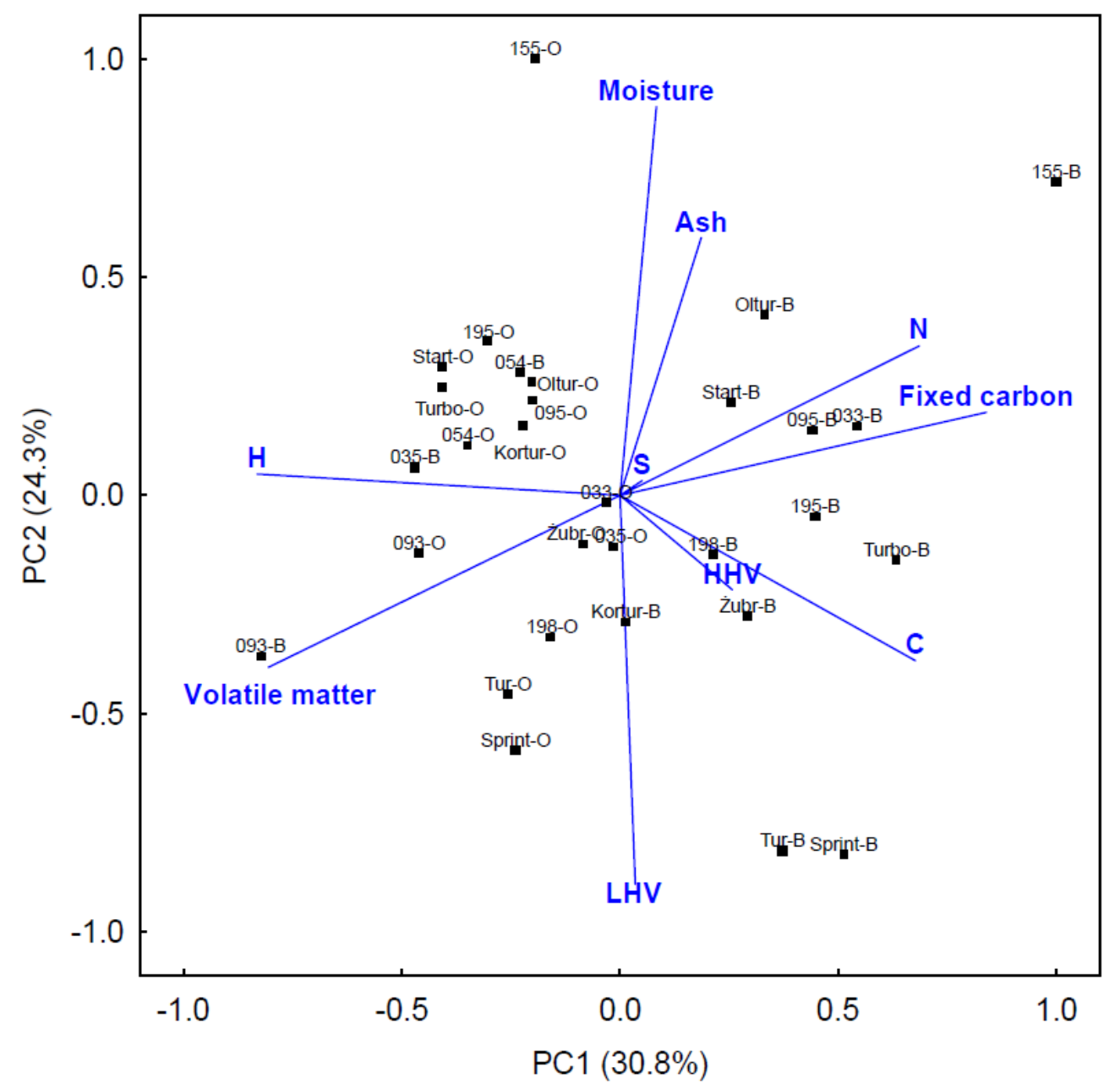

Figure 11. PCA biplot for tested willow biomass features. (To improve the readability of the chart, only the clone numbers are given without the note "UWM". The names of the varieties are given in full. "B" means Bałdy location, while "O" means Obory location).

Table 3. Factor loads of principal component analysis.

\begin{tabular}{cccc}
\hline Variable & PC1 & PC2 & PC3 \\
\hline Moisture & 0.08 & $\mathbf{0 . 8 9}$ & -0.12 \\
Ash & $\mathbf{0 . 1 9}$ & $\mathbf{0 . 5 9}$ & 0.2 \\
Fixed carbon & $\mathbf{0 . 8 4}$ & 0.19 & 0.17 \\
Volatile matter & $\mathbf{- 0 . 8}$ & -0.39 & -0.22 \\
HHV & 0.26 & -0.22 & $\mathbf{0 . 7 7}$ \\
LHV & 0.03 & $\mathbf{- 0 . 8 9}$ & 0.31 \\
C & $\mathbf{0 . 6 8}$ & -0.38 & 0.15 \\
H & $\mathbf{- 0 . 8 3}$ & 0.05 & 0.07 \\
S & 0.05 & 0.03 & $\mathbf{0 . 8 7}$ \\
N & $\mathbf{0 . 6 9}$ & 0.34 & 0.29 \\
\hline Eigenvalue & 3.08 & 2.43 & 1.69 \\
Explained variance $(\%)$ & 30.8 & 24.3 & 16.9 \\
\hline
\end{tabular}

Bold values indicate significance. 
Table 4. Percentage coefficients of variation (CV) for location, genotype, harvest rotation and-in general-for the willow biomass characteristics under study.

\begin{tabular}{ccccc}
\hline Variable & Location & Genotype & Rotation & Total \\
\hline Moisture & 3.36 & 3.28 & 3.31 & 3.54 \\
Ash & 11.01 & 10.96 & 12.13 & 13.08 \\
Fixed carbon & 1.63 & 1.09 & 1.86 & 2.63 \\
Volatile matter & 0.46 & 0.34 & 0.55 & 0.70 \\
HHV & 0.97 & 0.51 & 0.58 & 1.10 \\
LHV & 4.42 & 4.12 & 4.13 & 4.62 \\
C & 1.21 & 0.62 & 0.74 & 1.38 \\
H & 2.99 & 1.56 & 2.02 & 3.60 \\
S & 16.89 & 10.77 & 13.31 & 20.84 \\
N & 13.36 & 9.64 & 12.94 & 17.15 \\
\hline
\end{tabular}

\section{Conclusions}

The current study emphasised the significance of the impact of genotype (genetic factors), location (environmental factors) and harvest rotation and interactions of these factors on the variation of thermophysical properties and elemental composition of willow grown in the SRC system. Multidimensional analyses were conducted on a large number of biomass samples obtained from 15 genotypes grown at two different sites and harvested in two consecutive three-year harvest rotations. The genotype was found to largely determine the moisture content, ash content and the LHV. Therefore, it is noteworthy that to obtain willow biomass containing relatively low levels of ash and moisture and a high LHV, the right species, cultivars or clones need to be grown. In the current study, the lowest moisture content (and the highest LHV) was found in the biomass of S. viminalis. On the other hand, these characteristics were the least beneficial in the biomass of an S. dasyclados genotype. Moreover, in the case of LHV, the difference between these two genotypes was nearly $17 \%$ in favour of S. viminalis. The lowest ash contents were found in biomass of S. triandra, the Tur and Żubr cultivars of S. viminalis and a genotype of S. acutifolia, which contained a lower level of ash compared to the other genotypes. However, the highest value of this characteristic was again found in the biomass of a $S$. dasyclados clone. The location of the plantation and the local environmental conditions, as well as the genotype and the interactions of these factors may have a significant effect on the elemental biomass composition (C, H, N, S content). Therefore, one can expect a variation in the individual element contents in biomass obtained at different locations despite the fact that the same willow species, cultivars or clones are grown there. Therefore, it can be claimed the genetic diversity of willow, as well as the possibility of modifying the biomass composition by plant management show that these factors can be employed to optimise the quality of biomass obtained from an SRC plantation. However, to achieve it, more research is necessary, which will involve cooperation and information exchange between breeders of new cultivars, biomass producers and biomaterial end users, both in Poland and other countries and regions of the world, where willow biomass is cultivated and utilised.

Author Contributions: Conceptualization, M.J.S., M.K.; Data curation, M.J.S., M.K.; Formal analysis, M.J.S., M.K., D.Z., and K.W.; Funding acquisition, M.J.S.; Investigation, M.J.S. and M.K.; Methodology, M.J.S., M.K., K.W. and D.Z.; Project administration, M.J.S.; Validation, M.J.S., M.K., K.W. and D.Z.; Visualization, M.J.S., D.Z. and E.O.-Z.; Writing_original draft, M.J.S.; Writing—review \& editing, M.J.S., M.K., K.W., D.Z. and E.O.-Z. All authors have read and agreed to the published version of the manuscript.

Funding: This paper is the result of a long-term study carried out at the University of Warmia and Mazury in Olsztyn, Faculty of Environmental Management and Agriculture, Department of Plant Breeding and Seed Production, topic number 20.610.008-300 and it was co-financed by the National (Polish) Centre for Research and Development (NCBiR), entitled "Environment, agriculture and forestry", project: BIOproducts from lignocellulosic biomass derived from MArginal land to fill the Gap In Current national bioeconomy, No. BIOSTRATEG3/344253/2/NCBR/2017.

Acknowledgments: We would also like to thank the staff of the Department of Plant Breeding and Seed Production for their technical support during the experiments. 
Conflicts of Interest: The authors declare no conflict of interest.

\section{References}

1. Calvo Buendia, E.; Tanabe, K.; Kranjc, A.; Baasansuren, J.; Fukuda, M.; Ngarize, S.; Osako, A.; Pyrozhenko, Y.; Shermanau, P.; Federici, S. (Eds.) IPCC Intergovernmental Panel on Climate Change (IPCC). In 2019 Refinement to the 2006 IPCC Guidelines for National Greenhouse Gas Inventories; IPCC: Geneva, Switzerland, 2019.

2. Olabi, A.G. Energy quadrilemma and the future of renewable energy. Energy 2016, 108, 1-6. [CrossRef]

3. Foley, A.; Olabi, A.G. Renewable energy technology developments, trends and policy implications that can underpin the drive for global climate change. Renew. Sust. Energ. Rev. 2017, 68, 1112-1114. [CrossRef]

4. Pari, L.; Alfano, V.; Garcia-Galindo, D.; Suardi, A.; Santangelo, E. Pruning biomass potential in Italy related to crop characteristics, agricultural practices and agro-climatic conditions. Energies 2018, 11, 1365. [CrossRef]

5. Toscano, G.; Alfano, V.; Scarfone, A.; Pari, L. Pelleting vineyard pruning at low cost with a mobile technology. Energies 2018, 11, 2477. [CrossRef]

6. Eurostat. Energy. Energy statistics-quantities (nrg_quant). Available online: https://ec.europa.eu/eurostat/ web/energy/data/database (accessed on 28 January 2020).

7. Central Statistical Office. Energy from renewable sources in 2018. Available online: https://stat.gov. pl/en/topics/environment-energy/energy/energy-from-renewable-sources-in-2018,3,11.html (accessed on 21 April 2020).

8. Central Statistical Office. Forestry 2017. Available online: https://stat.gov.pl/en/publications/search.html? letter $=F \&$ page $=2$ (accessed on 21 April 2020).

9. Stolarski, M.J.; Niksa, D.; Krzyżaniak, M.; Tworkowski, J.; Szczukowski, S. Willow productivity from small and large-scale experimental plantations in Poland from 2000 to 2017. Renew. Sustain. Energy Rev. 2019, 101, 461-475. [CrossRef]

10. Stolarski, M.J.; Szczukowski, S.; Krzyżaniak, M.; Tworkowski, J. Energy value of yield and biomass quality in a 7-year rotation of willow cultivated on marginal soil. Energies 2020, 13, 2144. [CrossRef]

11. Stolarski, M.J.; Warmiński, K.; Krzyżaniak, M. Energy value of yield and biomass quality of poplar grown in two consecutive 4-year harvest rotations in the north-east of Poland. Energies 2020, 13, 1495. [CrossRef]

12. Serapiglia, M.J.; Cameron, K.D.; Stipanovic, A.J.; Abrahamson, L.P.; Volk, T.A.; Smart, L.B. Yield and woody biomass traits of novel shrub willow hybrids at two contrasting sites. Bioenergy Res. 2013, 6, 533-546. [CrossRef]

13. Manzone, M.; Bergante, S.; Facciotto, G. Energy and economic evaluation of a poplar plantation for woodchips production in Italy. Biomass Bioenergy 2014, 60, 164-170. [CrossRef]

14. Bioenergy Europe. Statistical Report 2019: Biomass Supply; Bioenergy Europe: Brussels, Belgium, $2019 ;$ p. 35.

15. Aronsson, P.; Rosenqvist, H.; Dimitriou, I. Impact of nitrogen fertilization to short rotation willow coppice plantations grown in Sweden on yield and economy. Bioenergy Res. 2014, 7, 993-1001. [CrossRef]

16. Cunniff, J.; Purdy, S.J.; Barraclough, T.J.P.; Castle, M.; Maddison, A.L.; Jones, L.E.; Shield, I.F.; Gregory, A.S.; Karp, A. High yielding biomass genotypes of willow (Salix spp.) show differences in below-ground biomass allocation. Biomass Bioenergy 2015, 80, 114-127. [CrossRef] [PubMed]

17. Djomo, S.N.; Witters, N.; Van Dael, M.; Gabrielle, B.; Ceulemans, R. Impact of feedstock, land use change, and soil organic carbon on energy and greenhouse gas performance of biomass cogeneration technologies. Appl. Energy 2015, 154, 122-130. [CrossRef]

18. Pacaldo, R.; Volk, T.; Briggs, R. Carbon sequestration in fine roots and foliage biomass offsets soil CO2 effluxes along a 19-year chronosequence of shrub willow (Salix x dasyclados) biomass crops. Bioenergy Res. 2014, 7, 769-776. [CrossRef]

19. Krzyżaniak, M.; Stolarski, M.J.; Szczukowski, S.; Tworkowski, J. Life cycle assessment of new willow cultivars grown as feedstock for integrated biorefineries. Bioenergy Res. 2016, 9, 224-238. [CrossRef]

20. Monedero, E.; Portero, H.; Lapuerta, M. Pellet blends of poplar and pine sawdust: Effects of material composition, additive, moisture content and compression die on pellet quality. Fuel Process. Technol. 2015, 132, 15-23. [CrossRef]

21. Nordborg, M.; Berndes, G.; Dimitriou, I.; Henriksson, A.; Mola-Yudego, B.; Rosenqvist, H. Energy analysis of willow production for bioenergy in Sweden. Renew. Sustain. Energy Rev. 2018, 93, 473-482. [CrossRef] 
22. Stolarski, M.J.; Warmiński, K.; Krzyżaniak, M.; Olba-Zięty, E.; Stachowicz, P. Energy consumption and heating costs for a detached house over a 12-year period - Renewable fuels versus fossil fuels. Energy 2020, 204, 117952. [CrossRef]

23. Aghaalikhani, A.; Savuto, E.; Di Carlo, A.; Borello, D. Poplar from phytoremediation as a renewable energy source: Gasification properties and pollution analysis. Energy Procedia 2017, 142, 924-931. [CrossRef]

24. Stolarski, M.J.; Szczukowski, S.; Tworkowski, J.; Krzyżaniak, M. Cost of heat energy generation from willow biomass. Renew. Energ. 2013, 59, 100-104. [CrossRef]

25. Tyśkiewicz, K.; Konkol, M.; Kowalski, R.; Rój, E.; Warmiński, K.; Krzyżaniak, M.; Gil, Ł.; Stolarski, M.J. Characterization of bioactive compounds in the biomass of black locust, poplar and willow. Trees 2019, 33, 1235-1263. [CrossRef]

26. Karp, A.; Shield, I. Bioenergy from plants and the sustainable yield challenge. New Phytol. 2008, 179, 15-32. [CrossRef] [PubMed]

27. Stolarski, M.J.; Warmiński, K.; Krzyżaniak, M.; Tyśkiewicz, K.; Olba-Zięty, E.; Graban, Ł.; Lajszner, W.; Załuski, D.; Wiejak, R.; Kamiński, P.; et al. How does extraction of biologically active substances with supercritical carbon dioxide affect lignocellulosic biomass properties? Wood Sci. Technol. 2020, 54, 519-546. [CrossRef]

28. Fabio, E.S.; Volk, T.A.; Miller, O.R.; Serapiglia, M.J.; Kemanian, A.R.; Montes, F.; Kuzovkina, Y.A.; Kling, G.J.; Smart, L.B. Contributions of environment and genotype to variation in shrub willow biomass composition. Ind. Crops Prod. 2017, 108, 149-161. [CrossRef]

29. Tharakan, P.J.; Volk, T.A.; Abrahamson, L.P.; White, E.H. Energy feedstock characteristics of willow and hybrid poplar clones at harvest age. Biomass Bioenergy 2003, 25, 571-580. [CrossRef]

30. Tharakan, P.J.; Volk, T.A.; Nowak, C.A.; Abrahamson, L.P. Morphological traits of 30 willow clones and their relationship to biomass production. Can. J. For. Res. 2005, 35, 421-431. [CrossRef]

31. Adler, A.; Verwijst, T.; Aronsson, P. Estimation and relevance of bark proportion in a willow stand. Biomass Bioenergy 2005, 29, 102-113. [CrossRef]

32. Novaes, E.; Osorio, L.; Drost, D.R.; Miles, B.L.; Boaventura-Novaes, C.R.D.; Benedict, C.; Dervinis, C.; Yu, Q.; Sykes, R.; Davis, M.; et al. Quantitative genetic analysis of biomass and wood chemistry of Populus under different nitrogen levels. New Phytol. 2009, 182, 878-890. [CrossRef]

33. Liu, N.; Jørgensen, U.; Lærke, P.E. Concentrations of chemical elements in willow biomass depend on clone, site and management in the field. Bioenergy Res. 2016, 9, 1216-1230. [CrossRef]

34. Larsen, S.U.; Jørgensen, U.; Kjeldsen, J.B.; Lærke, P.E. Effect of fertilisation on biomass yield, ash and element uptake in SRC willow. Biomass Bioenergy 2016, 86, 120-128. [CrossRef]

35. Stolarski, M.J.; Śnieg, M.; Krzyżaniak, M.; Tworkowski, J.; Szczukowski, S.; Graban, Ł.; Lajszner, W. Short rotation coppices, grasses and other herbaceous crops: Biomass properties versus 26 genotypes and harvest time. Ind. Crops Prod. 2018, 119, 22-32. [CrossRef]

36. Stolarski, M.J.; Krzyżaniak, M.; Załuski, D.; Niksa, D. Evaluation of biomass quality of selected woody species depending on the soil enrichment practice. Int. Agrophys. 2018, 32, 111-121. [CrossRef]

37. Krzyzaniak, M.; Stolarski, M.J.; Szczukowski, S.; Tworkowski, J. Thermophysical and chemical properties of biomass obtained from willow coppice cultivated in one- and three-year rotation cycles. J. Elem. 2015, 20, 161-175. [CrossRef]

38. Monedero, E.; Hernández, J.J.; Collado, R. Combustion-related properties of poplar, willow and black locust to be used as fuels in power plants. Energies 2017, 10, 997. [CrossRef]

39. Kauter, D.; Lewandowski, I.; Claupein, W. Quantity and quality of harvestable biomass from Populus short rotation coppice for solid fuel use-A review of the physiological basis and management influences. Biomass Bioenergy 2003, 24, 411-427. [CrossRef]

40. Serapiglia, M.J.; Gouker, F.E.; Smart, L.B. Early selection of novel triploid hybrids of shrub willow with improved biomass yield relative to diploids. BMC Plant Biol. 2014, 14, 74. [CrossRef]

41. Serapiglia, M.J.; Gouker, F.E.; Hart, J.F.; Unda, F.; Mansfield, S.D.; Stipanovic, A.J.; Smart, L.B. Ploidy level affects important biomass traits of novel shrub willow (Salix) hybrids. Bioenergy Res. 2015, 8, 259-269. [CrossRef]

42. Weger, J.; Hutla, P.; Bubeník, J. Yield and fuel characteristics of willows tested for biomass production on agricultural soil. Res. Agric. Eng. 2016, 4, 155-161. [CrossRef] 
43. Bajcar, M.; Zaguła, G.; Saletnik, B.; Tarapatskyy, M.; Puchalski, C. Relationship between torrefaction parameters and physicochemical properties of torrefied products obtained from selected plant biomass. Energies 2018, 11, 2919. [CrossRef]

44. Klasnja, B.; Kopitovic, S.; Orlovic, S. Wood and bark of some poplar and willow clones as fuelwood. Biomass Bioenergy 2002, 23, 427-432. [CrossRef]

45. Komorowicz, M.; Wróblewska, H.; Pawłowski, J. Chemical composition and energetic properties of biomass from selected renewable energy sources. Ochr. Śr. Zasobów Nat. 2009, 40, 402-410. (In Polish)

46. Jagustyn, B.; Patyna, I.; Skawińska, A. Evaluation of physicochemical properties of Palm Kernel Shell as agro biomass used in the energy industry. Chemik 2013, 67, 552-559.

47. Brosse, N.; Dufour, A.; Meng, X.Z.; Sun, Q.N.; Ragauskas, A. Miscanthus: A fast-growing crop for biofuels and chemicals production. Biofuel. Bioprod. Biorefin. 2012, 6, 580-598. [CrossRef]

48. Larsen, S.U.; Jørgensen, U.; Lærke, P.E. Biomass yield, nutrient concentration and nutrient uptake by SRC willow cultivars grown on different sites in Denmark. Biomass Bioenergy 2018, 116, 161-170. [CrossRef]

49. Forbes, E.G.A.; Johnston, C.R.; Archer, J.E.; McCracken, A.R. SRC willow as a bioremediation medium for a dairy farm effluent with high pollution potential. Biomass Bioenergy 2017, 105, 174-189. [CrossRef]

50. Larsen, S.U.; Jørgensen, U.; Lærke, P.E. Harvest interval and row spacing of SRC willow influence yield and nutrient content. Biomass Bioenergy 2019, 126, 181-189. [CrossRef]

51. Otepka, P.; Habán, M.; Habánová, M. Cultivation of fast-growing woody plant basket willow (Salix Viminalis L.) and their bioremedial abilities while fertilized with wood ash. Res. J. Agric. Sci. 2011, 43, 218-222.

52. Adler, A.; Dimitriou, I.; Aronsson, P.; Verwijst, T.; Weih, M. Wood fuel quality of two Salix viminalis stands fertilised with sludge, ash and sludge-ash mixtures. Biomass Bioenergy 2008, 32, 914-925. [CrossRef]

(C) 2020 by the authors. Licensee MDPI, Basel, Switzerland. This article is an open access article distributed under the terms and conditions of the Creative Commons Attribution (CC BY) license (http://creativecommons.org/licenses/by/4.0/). 